\title{
Who Don’t Want to Raise Genius Children?
}

\section{Alex Tate*}

Imperial College London, South Kensington Campus, London, UK

\begin{abstract}
New York City is a beautiful place. The hustle and bustle can be exciting and offer a rich ground for entertainment and activity. Although, New York may be a great place for adults, young children are often not able to enjoy and experience all the adventure and excitement the city offers. It is easy for a child to become restless and even hyperactive when they are not able to release energy as an adult can.
\end{abstract}

Keywords: Hyperactive; Excitement; Physical activity; Aerobic activity

\section{The Importance of Physical Activity}

Children need physical activity. An active child in a big city or a small home can be a challenge. Their limitless energy can be exhausting for a parent. The child may seem not to listen or be able to follow directions. They may seem to bounce off the walls or never stop moving. There is no quick fix for the active child. However, there are activities that can foster and guide that energy. Providing a structured environment and having enough patience to understand the child, are important elements in their development [1].

According to the World Health Organization (WHO's), children and youth ages 5-17 should average at least 60 minutes of aerobic activity a day (1) and, at least, another 90 minutes of other physical activity (5). This activity can be spread out throughout the day. Studies have shown that exercise promotes healthy muscles, bones and joints as well as heart, lungs, and coordination. Exercise can also help with a healthy body weight and with self-esteem (1). Activities can include sports, games, chores, or play and can occur in almost any environment. Getting the child in a habit of regular daily activity is a good way to start. Setting an example or doing the activity with them can accomplish engaging the child in developing a good attitude toward a habit of exercise and activity [2].

Active play can be structured or unstructured (5). Essentially this is a physical activity with bursts of energy. In structured play, the child follows rules or is guided through the play. These types of activity promote motor skills and brain skills. But, unstructured play is also important in that it allows the child freedom to be imaginative (5).

\section{Activity Ideas}

Children are active or even hyperactive as a normal process. Although children develop at different rates and their extra activity may vary from a few second to minutes there are some ways to help settle the energy even at the most inopportune times. Understanding that being fidgety is normal for a small child, the parent or caregiver can provide activities for the child that will allow them to sit for periods of time when it is necessary (2). Small movement may help the child, such as bouncing the child on a lap or allowing them to play with a small object or even a squishy stress ball. The movement may be all they need. Other ways to help the child sit in one spot is to give them something to such as coloring or drawing [3].

\section{Sports}

The most obvious activity is getting the child involved in sports. Depending on the child, some sports may be better than others. For example Karate or other Martial arts can help with concentration and self-discipline as well as a physical workout. But, it depends on the child's interest. Team sports also lend to developing social skills as well as given an outlet for focused energy.

\section{Creative}

There are other activities as well that can help the child burn off energy and provide learning experiences. Music classes can help with memorization and coordination and requires both sides of the brain to work together such as in multi-tasking. Dancing can also be a good way to channel energy while controlling their movements.

\section{Organizations}

Involvement in organizations can also be a way to promote activity Organizations such as Girl Scouts, Boy Scouts, YMCA or 4-H are other ways for a child to use up energy and learn teamwork. These groups also provide a good amount of structure that will channel the child's energy.

\section{Games}

Don't underestimate the use of simple games such as Bingo or Chess. Simpler games can be played with a child who has a shorter attention span. Games make the child use their brain that will use energy and promote thinking as well as build self-esteem.

\section{Get Creative}

Be creative when developing games. For example, use a balloon to play volleyball inside or using color paper or towel place the various colors on the floor with no same colors next to each other. Challenge the child to walk from one to room to another only stepping on one color (3). Listen to music and teach each other how to dance. Creating a treasure hunt can also be an activity to get the child moving and thinking. Give them clues on what objects to find. Make is more intensive by adding that they have to skip five steps or spell a word as part of the clue. The old game hot potato has the benefits of movement and coordination. Simon says, is another old game with benefits of coordination. But making jewelry or doing other crafts is equally beneficial.

*Corresponding author: Alex Tate, Department of Health Technology, Imperial College London, South Kensington Campus, London, UK, E-mail: alextate07@gmail.com

Received August 26, 2017; Accepted September 19, 2017; Published September 25, 2017

Citation: Tate A (2017) Who Don't Want to Raise Genius Children? J Health Med Informat 8: 287. doi: 10.4172/2157-7420.1000287

Copyright: () 2017 Tate A. This is an open-access article distributed under the terms of the Creative Commons Attribution License, which permits unrestricted use, distribution, and reproduction in any medium, provided the original author and source are credited. 


\section{Helping}

Helping around the house can also be made into fun. Completing chores with the parent or a buddy can be another way to use energy and teach pride in a job well done. Starting a small vegetable to flower garden is another activity that can be done as a team and will teach the child responsibility.

\section{What To Do in New York City (Parks, Theaters and More)}

In New York City there is a myriad of places to go and things to do. Central Park offers areas for children to run, playgrounds, carousel, and even a castle to play in as well biking and hiking trails. The aquarium offers children a chance to help feed some of the animals and a 4-D theater. There are spots for athletic exploration in Manhattan as well as a learning center. Brooklyn sports a gym park and Williamsburg has a place for kids to try rock-climbing and even zip lines. Other ways to promote activity include the Bounce House in New York City and nearby suburbs, the Children's Museum of Art, indoor ice skating rinks, skate parks and pools (6).

\section{Healthy Centers for immediate care}

New York City has many urgent care centers for immediate care. And they operate around the clock and no appointments needed. Having health services in your neighborhood is not less than a blessing.

Urgent Care Clinic also will provide any aftercare treatment that is needed. Ultimately, the patients are always the top priority and the focus of all the clinic's activities 365 days a year [1-3].

\section{Conclusion}

Activity is an important part of childhood development. Children can participate in many activities inside as well as outside in small spaces.
However, there are some safety issues to consider. First, make sure the child is participating in tasks that they can do or are age appropriate. Asking a 5-year-old to do complicated math to find a toy is only going to frustrate them. Make sure activities are supervised, especially for younger children. Use items or equipment that is safe for the child's age and coordination. Finally, make sure that the caregiver is aware of the child's surrounding especially if outside.

An active child should be given the opportunity to expel energy and to learn. Although unstructured activity is important, structured activities can help a child with self-esteem, coordination, self-discipline and physical development. Physical and mental activities not only keep the child busy but also can lay the foundation for a healthy and active lifestyle.

\section{Author Biography}

Alex Tate is an expert marketer who specializes in promoting and growing physician practices. He currently works with urgent way to help improve their online footprint and garner interest in their Urgent Care, Occupational Health and Health Services.

\section{References}

1. Tapia MD, Sow SO, Boubou T (2016) Maternal immunization with trivalent inactivated influenza vaccine for prevention of influenza in infants in Mali: a prospective, active-controlled, observer blind, randomized phase 4 trial. Lancet Infect Dis 3099: 30054-30058.

2. Thompson MG, Li DK, Shifflet $P$ (2014) Effectiveness of seasonal trivalent influenza vaccine for preventing influenza virus illness among pregnant women: a population-based case-control study during the 2010-2011 and 2011-2012 influenza seasons. Clin Infect Dis 58: 449-457.

3. Udell JA, Zawi R, Bhatt DL (2013) Association between influenza vaccination and cardiovascular outcomes in high-risk patients: a meta-analysis. JAMA 310 $1711-1720$ 